\title{
A CASE WITH EMANUEL SYNDROME: EXTRA DERIVATIVE 22 CHROMOSOME INHERITED FROM THE MOTHER
}

\author{
İkbal Atli E*, Gürkan H, Vatansever Ü, Ulusal S, Tozkir H
}

\begin{abstract}
*Corresponding Author: Emine İkbal Atli, Ph.D., Department of Medical Genetics, Faculty of Medicine, Trakya University, Campus Of Balkan, D100 Street, Edirne 22030, Turkey. Tel: +90-554-253-4030. Fax: +90284-223-4201. E-mail: emine.ikbal@gmail.com
\end{abstract}

\begin{abstract}
Emanuel syndrome (ES) is a rare chromosomal disorder that is characterized by multiple congenital anomalies and developmental disabilities. Affected children are usually identified in the newborn period as the offspring of balanced $(11 ; 22)$ translocation carriers. Carriers of this balanced translocation usually have no clinical symptoms and are often identified after the birth of offspring with an unbalanced form of the translocation, the supernumerary der(22) $\mathrm{t}(11 ; 22)$ syndrome. We report a 3-year-old boy with the $\mathrm{t}(11 ; 22)(\mathrm{q} 23 ; \mathrm{q} 11)$ chromosome, transmitted in an unbalanced fashion from his mother. He has several developmental delays; he is not independently ambulatory and language is significantly impaired. Using his peripheral blood, karyotyping was performed to define his multiple congenital anomalies, revealing the following chromosomal abnormality: $47, \mathrm{XY},+\operatorname{der}(22) \mathrm{t}(11 ; 22)(\mathrm{q} 23.3 ; \mathrm{q} 11.2)$. To ascertain the origin and trait of this supernumerary marker chromosome [der(22)t(11;22)(q23.3;q11.2)], karyotyping of his parents was performed. The mother was found to be a balanced carrier: $46, \mathrm{XX}, \mathrm{t}(11 ; 22)$ (q23.3; q11.2).
\end{abstract}

Keywords: Emanuel syndrome (ES); Karyotyping; Supernumerary; Translocation.

Department of Medical Genetics, Faculty of Medicine, Trakya University, Edirne, Turkey

\section{INTRODUCTION}

Emanuel syndrome (ES) is an unbalanced translocation syndrome, usually arising through a 3:1 meiosis I malsegregation during gametogenesis in a phenotypically balanced translocation normal carrier. While the true mortality rate in Emanuel syndrome is unknown, long-term survival is possible [1]. Emanuel syndrome is also referred to as derivative 22 syndrome, derivative 11;22 syndrome, partial trisomy $11 ; 22$, or supernumerary $\operatorname{der}(22) \mathrm{t}(11 ; 22)$ syndrome [2]. In this partial duplication, 11(q23-qter) and 22(pter-q11) complex, congenital diaphragmatic hernia has been observed [3]. There is growth retardation, mental retardation (severe), cardiovascular malformation, craniofacial anomalies (including pre auricular tags or sinuses, micrognathia, ear anomalies, cleft or high-arched palate), microcephaly, kidney abnormalities and genital abnormalities in males $[1,4]$.

\section{CASE REPORT}

We report a 3 -year-old boy with the $t(11 ; 22)$ (q23;q11) chromosome, transmitted in an unbalanced fashion from his mother. It was her first pregnancy; the patient's mother and grandmother have no history of the disease (Figure 1). The prenatal period of the infant was uneventful. The infant was delivered at full-term by vaginal delivery. His birth weight was $3.25 \mathrm{~kg}$, length $52 \mathrm{~cm}$. At birth, he was found to have a cleft palate, micrognathia, undescended testis, in- 


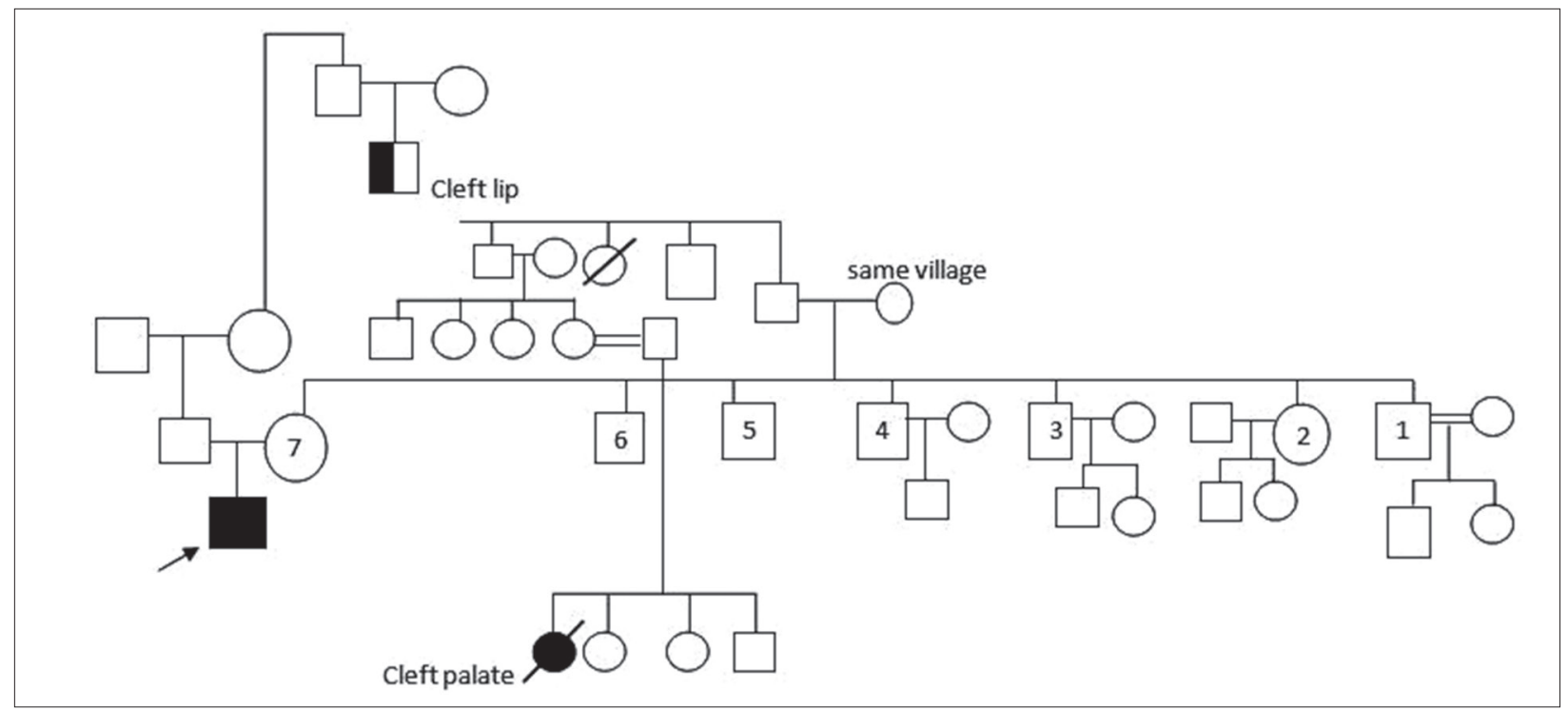

Figure 1. Pedigree of patient

guinal hernia, and surgery was performed to correct these anomalies (Figure 2).

$\mathrm{He}$ is now 3 years old and echocardiography revealed a secundum atrial septal defect of about 10 $\mathrm{mm}$. He also has central nervous system (CNS) and skeletal anomalies, mental retardation, hypotonia, white matter abnormalities, cerebral atrophy, scoliosis, kyphosis and glaucoma. On hearing assessment, he has bilateral hearing loss. He has gallstones and feeding problems. He was admitted to our hospital repeatedly due to respiratory infections and recurrent ear infections. His head circumference is $48 \mathrm{~cm}$ and he has a short neck with low posterior hairline. Magnetic resonance imaging (MRI) showed lateral ventricles are enlarged to approximately $22 \mathrm{~mm}$ (Fig-

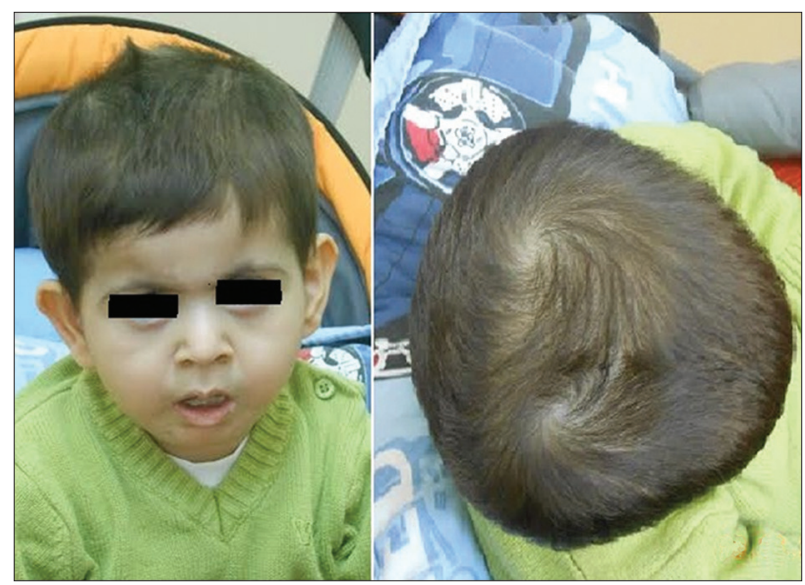

Figure 2. The photograph shows the facial and head features of the patient. ure 3). He has several developmental delays; he is not independently ambulatory and language is significantly impaired.

Using his peripheral blood, karyotyping was performed to define his multiple congenital anomalies, revealing the chromosomal abnormality $47, \mathrm{XY},+\operatorname{der}(22) \mathrm{t}(11 ; 22)$ (q23.3; q11.2) (Figure 4). To ascertain the origin and trait of this supernumerary marker chromosome [der(22) $\mathrm{t}(11 ; 22)(\mathrm{q} 23.3 ; \mathrm{q} 11.2)]$ karyotyping of his parents was performed. The mother was found to be a balanced carrier: $46, \mathrm{XX}$, $\mathrm{t}(11 ; 22)$ (q23.3;q11.2) (Figure 5). We used fluorescent in situ hybridization (FISH) probes for the 22q11.2 and 22q13.3 deletions and identified the supernumerary chromosome der(22)t(11;22) (Figure 6)/maternal

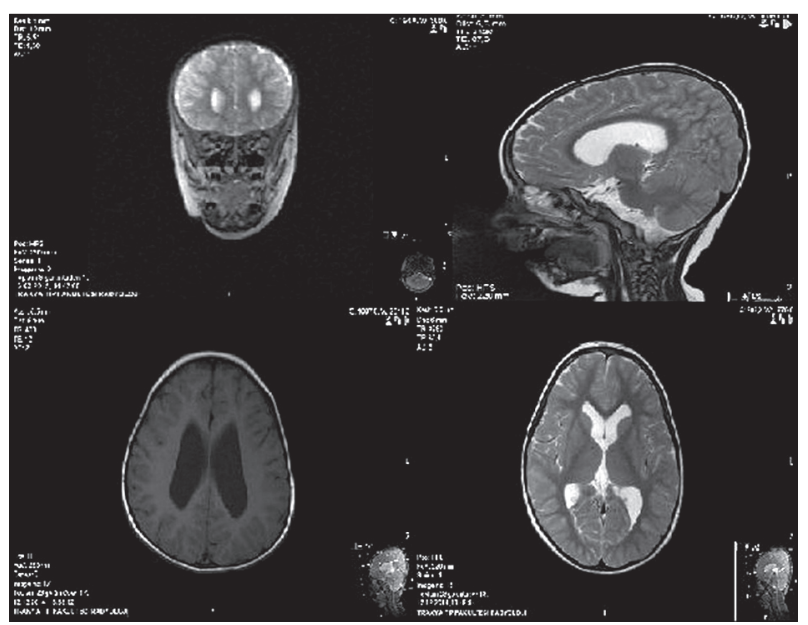

Figure 3. Cranial MRI image of case 


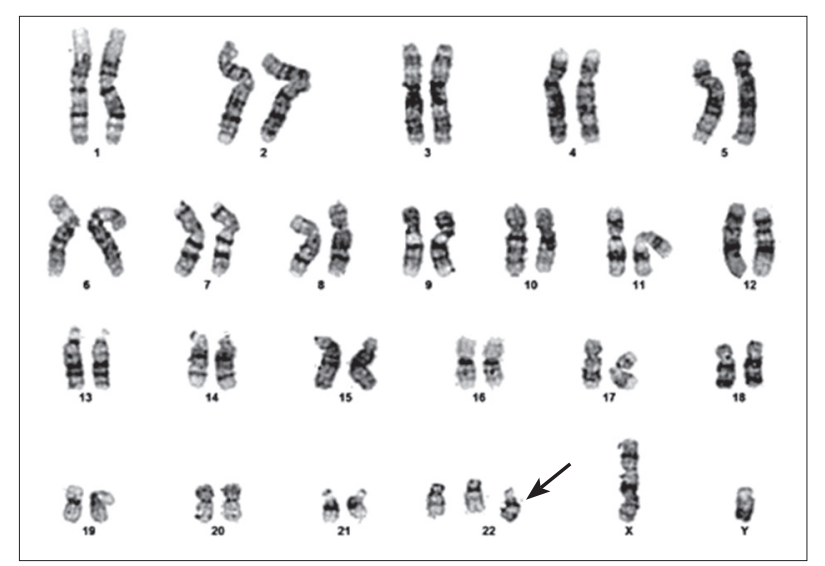

Figure 4. Karyotype of case $+\operatorname{der}(22) \mathrm{t}(11 ; 22)$ (arrowheads)

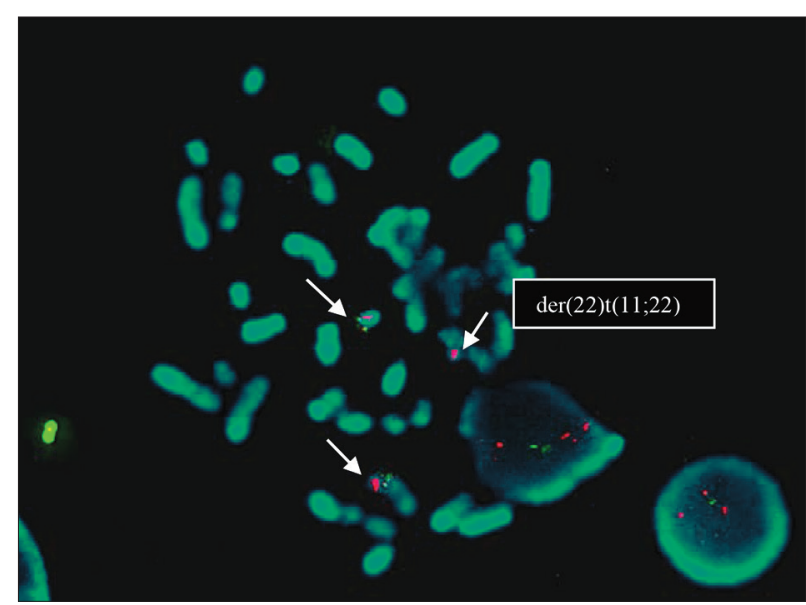

Figure 6. Fluorescent in situ hybridization image of the patient with $\operatorname{der}(22) \mathrm{t}(11 ; 22)$; green signals the $22 \mathrm{q} 13.3$ and red signals the $22 \mathrm{q} 11.21$ region.

$\mathrm{t}(11 ; 22)$ (q23.3;q11.2) (Figure 7). We used Aquarius ${ }^{\circledR}$ Microdeletion Syndrome probes, DiGeorge/ VCFS TUPLE 1 and 22q13.3 Deletion Syndrome Probe Combination (Cytocell Ltd., Cambridge, UK).

\section{DISCUSSION}

The recurrent constitutional $\mathrm{t}(11 ; 22)(\mathrm{q} 23 ; \mathrm{q} 11)$ is the most frequent non Robertsonian translocation in humans. Similar to Robertsonian translocations and many other recurrent or non recurrent constitutional translocations, balanced carriers of the $\mathrm{t}(11 ; 22)$ translocation usually have no clinical symptoms because this rearrangement does not disrupt functional genes. Balanced carriers, however, often have reproductive problems such as male infertility, recurrent pregnancy loss, and the birth of offspring with a chromosomal

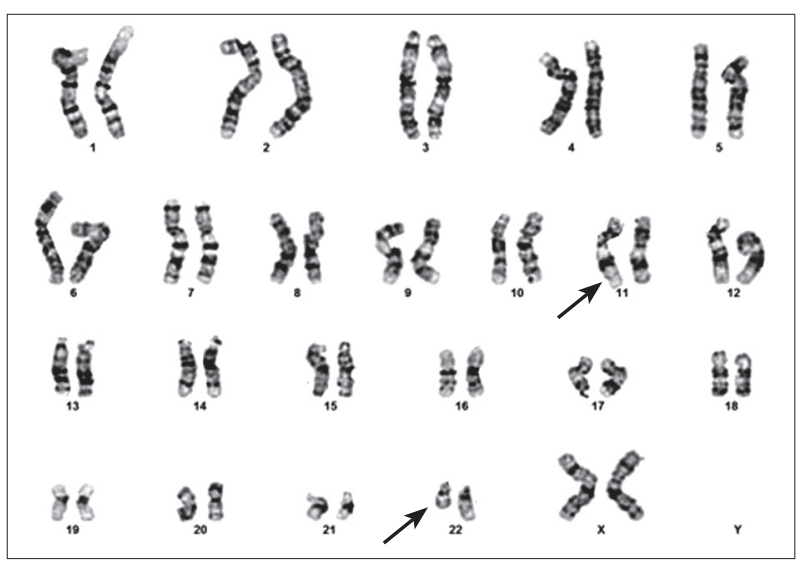

Figure 5. Karyotype of the mother $[\mathrm{t}(11 ; 22)(\mathrm{q} 23.3 ; \mathrm{q} 11.2)]$.

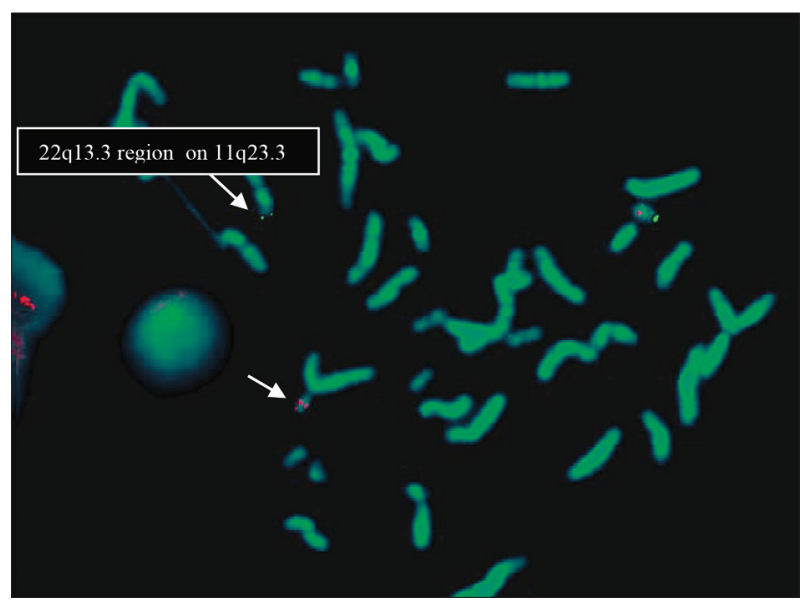

Figure 7. Fluorescent in situ hybridization image of the mother with $\mathrm{t}(11 ; 22)(\mathrm{q} 23.3 ; \mathrm{q} 11.2)$; green signals the $22 \mathrm{q} 13.3$ and red signals the $22 \mathrm{q} 11.21$ region.

imbalance. Severely affected offspring have supernumerary $\operatorname{der}(22) t(11 ; 22)$ syndrome [5] as a result of a 3:1 meiotic malsegregation of $\operatorname{der}(22)(4)$. The clinical features of ES arises from duplication of 22q10-22q11 and duplication of 11q23-qter on the supernumerary der(22) [2]. The exact incidence is unknown. This is a rare syndrome with reported cases of around 100. Male and female balanced carriers have a 0.7 and $3.7 \%$ risk of having children with supernumerary der(22), respectively. Clinical testing such as chromosomal analysis, FISH testing, whole chromosome paint (WCP), array genomic hybridization (aGH), or multiple ligation-dependent probe amplification (MLPA) (MRC-Holland, Amsterdam, The Netherlands) assay can be performed for the diagnosis of this syndrome. Highest mortality is in the first few months of life. While the true mortality 
rate in ES is unknown, long-term survival is possible, especially if the patient survives the infancy period. The reported case had all the classical features of ES [2] (Table 1).

Almost all children with ES have global developmental delays and intellectual disabilities. Table 2 shows the list of clinical features observed in Emanuel syndrome. Management involves a multi disciplinary team approach involving pedodontist, pediatrician, plastic surgeon, geneticist, gastrologist, speech therapist, urologist, cardiologist, ear, nose and throat (ENT) surgeon and ophthalmologist. Two issues are impor-

Table 1. List of reported cases of Emanuel syndrome.

\begin{tabular}{|c|c|c|}
\hline$n$ & References & $\begin{array}{l}\text { Reported } \\
\text { Cases }(n)\end{array}$ \\
\hline 1 & $\begin{array}{l}\text { Zaki MS, Mohamed AM, Kamel AK, El-Gerzawy AM, El-Ruby MO. Emanuel syndrome due to unusual } \\
\text { segregation of paternal origin. Genet Counsel. 2012; 23(2): 319-328. }\end{array}$ & 1 \\
\hline 2 & $\begin{array}{l}\text { Walfisch A, Mills KE, Chodirker BN, Berger H. Prenatal screening characteristics in Emanuel syndrome: } \\
\text { A case series and review of literature. Arch Gynecol Obstet. 2012; 286(2): 199-302. }\end{array}$ & 5 \\
\hline 3 & $\begin{array}{l}\text { Kim HJ, Kim YM, Lee HB, Kim JH, Seo EJ, Yoo HW. A case with Emanuel syndrome resulting from a } \\
\text { maternal translocation. J Med Genet. 2012; 9(1): 35-37. }\end{array}$ & 1 \\
\hline 4 & $\begin{array}{l}\text { Carter MT, St Pierre SA, Zackai EH, Emanuel BS, Boycott KM. Phenotypic delineation of Emanuel } \\
\text { syndrome (supernumerary derivative } 22 \text { syndrome): Clinical features of } 63 \text { individuals. Am J Med Genet } \\
\text { Part A. 2009; 149A(8): 1712-1721. }\end{array}$ & 63 \\
\hline 5 & $\begin{array}{l}\text { Toyoshima M, Yonee C, Maegaki Y, Yamamoto T, Shimojima K, Maruyama S, et al. Vertebral fusion in a } \\
\text { patient with supernumerary-der(22)t(11;22). Am J Med Genet A. 2009;149(8): 1722-1726. }\end{array}$ & 1 \\
\hline 6 & $\begin{array}{l}\text { Emanuel BS. Molecular mechanisms and diagnosis of chromosome 22q11.2 rearrangements. Dev Disabil } \\
\text { Res Rev. 2008; 14(1): 11-18. }\end{array}$ & 1 \\
\hline 7 & $\begin{array}{l}\text { Prieto JC, Garcia NM, Elder FF, Zinn AR, Baker LA. Phenotypic expansion of the supernumerary } \\
\text { derivative (22) chromosome syndrome: VACTERL and Hirschprung's disease. J Pediatr Surgery. 2007; } \\
\text { 42(11): 1928-1932. }\end{array}$ & 1 \\
\hline 8 & $\begin{array}{l}\text { Crolla JA, Youings SA, Ennis S, Jacobs PA. Supernumerary marker chromosomes in man: Parental origin, } \\
\text { mosaicism and maternal age reviseted. Eur J Hum Genet. 2005; 13(2): 154-160. }\end{array}$ & 1 \\
\hline 9 & $\begin{array}{l}\text { Hou JW. Supernumerary chromosome marker der(22)t11;22) resulting from a maternal balanced } \\
\text { translocation. Chang Gung Med J. 2003; 26(1): 48-52. }\end{array}$ & 1 \\
\hline 10 & $\begin{array}{l}\text { Rosias PPR, Sijstermans JMJ, Theunissen PMVM, Pulles-Heintzberger CF, De Die-Smulders CE, Engelen } \\
\text { JJ, et al. Phenotypic variability of the cat eye syndrome. Case report and review of the literature. Genet } \\
\text { Counsel. 2001; 12(3): } 273-282 \text {. }\end{array}$ & 1 \\
\hline 11 & $\begin{array}{l}\text { Estop AM, Cieply KM, Munne S, Feingold E. Multicolor fluorescence in situ hybridization analysis of the } \\
\text { spermatozoa of a male heterozygous for a reciprocal translocation } \mathrm{t}(11 ; 22)(\mathrm{q} 23 ; \mathrm{q} 11) \text {. Hum Genet. 1999; } \\
\text { 104(5): 412-417. }\end{array}$ & 1 \\
\hline 12 & $\begin{array}{l}\text { Funke B, Edelmann N, McCain N, Pandita RK, Ferreira J, Merscher S, et al. Der(22) syndrome and verlo- } \\
\text { cardio-facial syndrome/DiGeorge syndrome share a } 1.5 \mathrm{Mb} \text { region of overlap on chromosome 22q11. Am J } \\
\text { Hum Genet. 1999; 64(3): 747-758. }\end{array}$ & 1 \\
\hline 13 & $\begin{array}{l}\text { Shaikh TH, Budarf ML, Celle L, Zackai EH, Emanuel BS. Clustered 11q23 and 22q11 breakpoints and 3:1 } \\
\text { meiotic masegregation in multiple unrelated t(11;22) families. Am J Hum Genet. 1999; 65(6): 1595-1607. }\end{array}$ & 1 \\
\hline 14 & $\begin{array}{l}\text { Dawson AJ, Mears AJ, Chudley AE, Bech-Hansen T, McDermid H. Der(22)t }(11 ; 22) \text { resulting from a } \\
\text { paternal de novo translocation, adjacent } 1 \text { segregation, and maternal heterodisomy of chromosome } 22 . \mathrm{J} \\
\text { Med Genet. 1996; 33(1): 952-956. }\end{array}$ & 1 \\
\hline 15 & $\begin{array}{l}\text { Beedgen B, Nützenadel W, Querfeld U, Weiss-Wichert P. Partial trisomy } 22 \text { and } 11 \text { due to a paternal 11;22 } \\
\text { translocation associated with Hirschsprung disease. Eur J Pediatr. 1986; 145(3): 229-232. }\end{array}$ & 1 \\
\hline 16 & $\begin{array}{l}\text { Fraccaro M, Lindsten J, Ford CE, Iselius L. The 11q;22q translocation: A European collaborative analysis } \\
\text { of } 43 \text { cases. Hum Genet. 1980; 56(1): 21-51. }\end{array}$ & 1 \\
\hline 17 & $\begin{array}{l}\text { Pfeifer RA, Kessel EK, Soer KH. Partial trisomies of chromosome } 21 \text { in man. Two new observations due } \\
\text { to translocations } 19 ; 21 \text { and 4;21. Clin Genet. } 1977 ; 11(2): 207-213 \text {. }\end{array}$ & 1 \\
\hline
\end{tabular}


Table 2. List of clinical features observed in Emanuel syndrome.

\begin{tabular}{|c|c|c|}
\hline System Involved & Clinical Features & Our Case \\
\hline 1. Growth and development & $\begin{array}{l}\text { Pre- and postnatal growth retardation, delayed } \\
\text { speech and language development }\end{array}$ & $\begin{array}{l}\text { Delayed speech and language development, } \\
\text { feeding problems, not independently ambulatory }\end{array}$ \\
\hline 2. Craniofacial anomalies & $\begin{array}{l}\text { Microbrachycephaly, prominent forehead, } \\
\text { epicanthal folds, downslanting palpebral } \\
\text { fissures, broad and flat nasal bridge, long } \\
\text { pronounced philtrum, abnormal auricles, } \\
\text { preauricular ear pits and/or tags }(76.0 \%) \text {, } \\
\text { deafness and otitis media }\end{array}$ & $\begin{array}{l}\text { Otitis media, preauricular tags or sinuses, } \\
\text { bilateral hearing loss, lateral ventricles are } \\
\text { enlarged by } \sim 22 \mathrm{~mm} \text {, short neck, low posterior } \\
\text { hairline, glaucoma }\end{array}$ \\
\hline 3. Central nervous system & $\begin{array}{l}\text { Most commonly, microcephaly present seizures, } \\
\text { failure to thrive and delayed psychomotor } \\
\text { development }\end{array}$ & $\begin{array}{l}\text { Delayed psychomotor development, white } \\
\text { matter abnormalities, cerebral atrophy, } \\
\text { microcephaly }\end{array}$ \\
\hline 4. Cardiac defects & $\begin{array}{l}\text { Sixty percent of individuals with congenital } \\
\text { heart defects such as atrial septal defect, } \\
\text { ventricular septal defect, Tetralogy of Fallot and } \\
\text { patent ductus arteriosus }\end{array}$ & Secundum atrial septal defect \\
\hline 5. Genitointestinal defects & $\begin{array}{l}\text { Diaphragmatic hernia, anal atresia, inguinal } \\
\text { hernias, biliary atresia, small penis }(64.0 \%) \text { and } \\
\text { cryptorchidism }(46.0 \%)\end{array}$ & $\begin{array}{l}\text { Complex congenital diaphragmatic hernia, } \\
\text { inguinal hernias, undescended testes, gallstones }\end{array}$ \\
\hline 6. Musculoskeletal defects & $\begin{array}{l}\text { Most commonly, centrally based hypotonia, } \\
\text { congenital hip dislocation, arachnodactyly, club } \\
\text { foot and joint, syndactyly of the toes, delayed } \\
\text { bone age and hyperextensibility of joints }\end{array}$ & Hypotonia, scoliosis, kyphosis \\
\hline 7. Oral findings & $\begin{array}{l}\text { Cleft palate }(50.0 \%) \text {, micrognathia }(60.0 \%) \text {, } \\
\text { angular mouth pits, bifid uvula and facial } \\
\text { asymmetry }\end{array}$ & Micrognathia, cleft or high-arched palate \\
\hline 8. Immunological defects & Congenital immunological deficiency & Congenital immunological deficiency \\
\hline 9. Renal defects & Renal defects $(36.0 \%)$ & Kidney abnormalities \\
\hline
\end{tabular}

tant in terms of genetic counseling of these families. First, when one parent is a carrier of $t(11 ; 22)$, future pregnancies are at an increased risk for either ES, balanced $\mathrm{t}(11 ; 22)$, or another meiotic malsegregation, thus, prenatal cytogenetic testing should be offered for future pregnancies. Secondly, carrier testing of the unaffected siblings should normally be offered when they have reached adulthood and are able to understand the reproductive implications of being a carrier [2].

Declaration of Interest. The authors report no conflicts of interest. The authors alone are responsible for the content and writing of this article.

\section{REFERENCES}

1. Carter MT, St Pierre SA, Zackai EH, Emanuel BS, Boycott KM. Phenotypic delineation of Emanuel syndrome (supernumerary derivative
22 syndrome): Clinical features of 63 individuals. Am J Med Genet Part A. 2009; 149A(8): 1712-1721.

2. Choudhary MG, Babaji P, Sharma N, Dhamankar D, Naregal G, Reddy VS. Derivative 11;22 (emanuel) syndrome: A case report and a review. Case Reports Pediatr. 2013; 2013: 237935. doi: 10.1155/2013/237935.

3. Kadir RA, Hastings R, Economides DL. Prenatal diagnosis of supernumerary chromosome derivative (22) due to maternal balanced translocation in association with diaphragmatic hernia: A case report. Prenat Diagn. 1997; 17(8): 761-764.

4. Ohye T, Inagaki H, Kato T, Tsutsumi M, Kurahashi H. Prevalence of Emanuel syndrome: Theoretical frequency and surveillance result. Pediatr Int. 2014; 56(4): 462-466.

5. OMIM 609029, Emanuel syndrome (http://www. omim.org/entry/609029). 
